\title{
Autotomy and Regeneration in Squamate Reptiles (Squamata, Reptilia): Defensive Behavior Strategies and Morphological Characteristics (Using Computer Microtomography Methods)
}

\author{
D. A. Gordeev ${ }^{a}$, N. B. Ananjeva ${ }^{b, *}$, and D. V. Korost ${ }^{c}$ \\ ${ }^{a}$ Volgograd State University, Volgograd, 400062 Russia \\ ${ }^{b}$ Zoological Institute, Russian Academy of Sciences, St. Petersburg, 199034 Russia \\ ${ }^{c}$ Faculty of Biology, Moscow State University, Moscow, 119991 Russia \\ *e-mail: nananjeva09@gmail.com \\ Received January 12, 2020; revised February 6, 2020; accepted February 6, 2020
}

\begin{abstract}
It has been noted that caudal autotomy as a way of defending against predators in recent reptiles is characteristic solely of lepidosaurs and is absent in crocodiles and turtles. It was found that, in the order Rhynchocephalia and in representatives of the majority of families of lizards, intravertebral (IntraVB) autotomy is a widespread phenomenon, whereas agamid lizards and some snakes do not have a break plane, and their tails break between adjacent vertebrae (intervertebral (InterVB) autotomy). The frequencies of occurrence of InterVB autotomy and regeneration in six species of agamas of the genus Paralaudakia were analyzed. Six types of regenerate's characteristic of the studied group and the anatomical structure of the knob -shaped jagged regenerate are described on the basis of the results of computed microtomography (micro-CT). Phenomena of autotomy and regeneration are discussed in the phylogenetic context.
\end{abstract}

DOI: $10.1134 / \mathrm{S} 1062359020040068$

\section{INTRODUCTION}

Autotomy in the form of tail shedding is one of the most remarkable features of many lepidosaurs, but it is not known in crocodiles and turtles. Caudal autotomy is characteristic of the majority of families of recent lizards, some snakes (mostly colubrids), and the majority of amphisbaenid families (Arnold, 1984, 1988; Ananjeva and Orlov, 1994; Savage and Slowinski, 1996; Bowen, 2004; Costa et al., 2014; Crnobrija-Isalović et al., 2016). Two ways of defending against predators are known. Intravertebral (IntraVB) autotomy, when rupture occurs through the vertebral body at "weak sites," is a more widespread phenomenon. It is characteristic of the lepidosaurs of the order Rhynchocephalia as well as of squamate reptiles of the families Scincidae, Cordylidae, Teiidae, Xantusiidae, Anguidae, Lacertidae, some Iguanidae, and the majority of Gekkota (families Carphodactylidae, Diplodactylidae, Gekkonidae, Eublepharidae, Phyllodactylidae, and Sphaerodactylidae). Intervertebral (InterVB) autotomy, when break planes are absent and tail breakage occurs between adjacent vertebrae, is less common. It is reliably observed in the autotomy-capable lizards of the family Agamidae and in some snakes (mainly of the families Colubridae, Lamprophiidae, and Natricidae). InterVB autotomy in snakes is not accompanied by subsequent regeneration. According to the previously proposed terminology (Savage and
Slowinski, 1996; Costa et al., 2014), the following types of breaks are distinguished: urotomy (any type, both inter- and intravertebral); autotomy per se (which, according to the authors, include only the IntraVB type of break with subsequent regeneration of the lost part), and pseudo-autotomy (an intervertebral nonspontaneous type of tail fracture without regeneration). Analysis of the data published over the entire study period (Crnobrija-Isalović et al., 2016) showed the following frequencies of pseudo-autotomy in different families of snakes: in Colubridae (in 46 species of 34 genera, $41 \%$ of species), in Lamprophiidae (in four species of two genera (25\%)), in Viperidae (in two species of two genera), and in Elapidae (only in one species). In this classification, agamid lizards are not assigned to any of the above categories; they occupied an indefinite position ("intermediate condition") (Savage and Slowinski, 1996).

The first way is considered as a plesiomorphic state in squamate reptiles (Reptilia: Squamata) but is independently lost in many evolutionary lines (Arnold, 1984). Apparently, the absence of IntraVB autotomy among representatives of many monophyletic families indicates that the ability to shed the tail in this way was lost several times during their evolutionary history (Arnold, 1988). In most cases, the formed regenerate differed significantly from the original part of the tail 
that had not undergone autotomy by a change in color, scaling pattern, and general proportions.

Various ecological, functional, morphological, and evolutionary aspects of autotomy as defensive behavior strategies have been studied: caudal bi- and trifurcation (Ananjeva and Danov, 1991; Dudek and EknerGrzyb, 2014; Pheasey et al., 2014; Koleska and Jablonski, 2015; Passos et al., 2016; Pelegrin and Leão, 2016; Gordeev, 2017; Kolenda et al., 2017; Vergilov and Natchev, 2017; Kukushkin, 2018; Koleska, 2018; Maria and Al-Razi, 2018; Ramadanović and Zimić, 2019), regulation of the formation of the cartilaginous tube (Lozito and Tuan, 2015), and the histochemistry and ultrastructure of the regenerated epidermis (Alibardi and Maderson, 2003). Experiments were also performed on spinal cord implantation (Lozito and Tuan, 2016); localization of proliferating cells (Alibardi, 2016); physiology (Meyer et al., 2002); bioenergetics of autotomy, regeneration, and post-autotomy locomotion (Pafilis et al., 2005; Lin et al., 2006; Seligmann et al., 2008; Sun et al., 2009; Fleming et al., 2013); and the rate and molecular mechanisms of regeneration (Pillai et al., 2013; Yadav et al., 2014; Hutchins et al., 2016; Alibardi, 2017). The frequencies of occurrence of autotomy and pseudo-autotomy (Bowen, 2004; Arribas, 2014; Costa et al., 2014) and the effect of tail regeneration on the locomotor activity of lizards (Chapple and Swain, 2002; Jagnandan et al., 2014; Zamora-Camacho et al., 2016) were studied. The authors of a study that summarized the most significant information over the past 200 years described the prospects for future research (Higham et al., 2013). The majority of the numerous publications on problems of autotomy considered a limited number of species with the IntraVB autotomy mechanism, whereas the morphology of the regenerates that are formed in species with the intervertebral break was considered very rarely (Schall et al., 1989). The purpose of this study was to analyze the autotomy and morphology of tail regenerates in agamid lizards by computed microtomography methods (micro-CT) using the genus Paralaudakia Baig Wagner, Ananjeva and Böhme, 2012 as an example.

\section{MATERIALS AND METHODS}

The material for this study was specimens of the herpetological collections of the Zoological Institute, Russian Academy of Sciences (ZIN RAS, St. Petersburg), and the Zoological Museum, Moscow State University (ZM MSU, Moscow). A total of 614 specimens were studied, which were represented by series of six species: the Caucasian agama Paralaudakia caucasia (Eichwald, 1831), the redbelly rock agama $P$. erythrogaster (Nikolsky, 1896), the Himalayan agama P. himalayana (Steindachner, 1867), the Turkestan rock agama P. lehmanni (Nikolsky, 1896), the smallscaled rock agama $P$. microlepis (Blanford, 1875), and the Mongolian rock agama $P$. stoliczkana (Blanford,
1875). The following classification was used to analyze the autotomy localization (Arribas, 2014): intact tail and autotomy in the distal third, the middle, and the proximal third of the tail. The frequency of occurrence of autotomy and various regeneration states was estimated by nonparametric statistical methods. To assess the possibility of comparison of different regeneration states in the series, we analyzed the proportionality of the number of females, males, and specimens at the juvenile stage (Kruskel-Wallis, Mann-Whitney, and Fisher (F) tests). The calculations were performed using the PAST 3.22 software.

The anatomical structure of the regenerates was studied by the micro-CT method (Moscow State University, Moscow) using a SkyScan-1172 desktop scanner (Bruker micro-CT, Kontich, Belgium) equipped with a Hamamatsu $10 \mathrm{Mp}$ digital camera. The tails of P. caucasia (R-15396, ZM MSU) and P. himalayana (36556, ZM MSU) were scanned. The tail samples were placed in a plastic vessel and scanned sequentially. Scanning was performed with a resolution of $6.19 \mu \mathrm{m}$ at a source voltage of $40 \mathrm{kV}$ and current strength of $250 \mu \mathrm{A}$ with a turn step of $0.2^{\circ}$ and a shutter speed of $1600 \mathrm{~ms}$ for the $P$. caucasia specimen and with a resolution of $12.39 \mu \mathrm{m}$ at a source voltage of $40 \mathrm{kV}$ and current of $250 \mu \mathrm{A}$ with a turn step of $0.3^{\circ}$ and a shutter speed of $800 \mathrm{~ms}$ for the $P$. himalayana specimen. The resulting subscan data arrays were connected vertically to obtain the general tomogram. Data were processed using the Skyscan software DataViewer, CTAn, and CTVol (creation and visualization of 3D models).

\section{RESULTS AND DISCUSSION}

The majority of specimens of rock ring-tailed agamas Paralaudakia Baig Wagner, Ananjeva and Böhme, 2012, that were studied by us had intact tails (Table 1): from $53.6 \%$ in P. erythrogaster to $87.4 \%$ in P. lehmanni. In P. microlepis, the frequency of occurrence of specimens with whole tails was $40.0 \%$, which can be explained by the small sample size $(n=5)$. The number of specimens with autotomy in the presented series is smaller: from $12.6 \%$ in P. lehmanni to $46.4 \%$ in P. erythrogaster.

In $P$. caucasia, the proportions of females and males with shed tails were very close (37.1 and $38.5 \%$, respectively). In most specimens ( $13.1 \%$ of females and $17.3 \%$ of males), autotomy occurred in the distal third of the tail, whereas other cases (autotomy in the middle or proximal third of the tail) were quite rare and did not exceed $4.0 \%$.

In P. erythrogaster, the frequencies of occurrence of autotomized specimens and specimens with intact tails were the closest compared to the other species considered (46.4 and $53.6 \%$, respectively), and the frequencies of occurrence of females and males with shed tails were nearly identical (44.4 and 47.4\%). 
Table 1. Frequency of caudal autotomy in rock ring-tailed agamas of the genus Paralaudakia

\begin{tabular}{|c|c|c|c|c|c|c|c|c|c|c|c|c|c|c|c|}
\hline \multirow{3}{*}{ Species } & \multirow{2}{*}{\multicolumn{3}{|c|}{$\begin{array}{l}\text { Number } \\
\text { of specimens } \\
\text { in series }\end{array}$}} & \multirow{2}{*}{\multicolumn{3}{|c|}{$\begin{array}{c}\text { Number } \\
\text { of specimens in series } \\
\text { with intact tails }\end{array}$}} & \multicolumn{9}{|c|}{ Autotomy with subsequent regeneration } \\
\hline & & & & & & & \multicolumn{3}{|c|}{$\begin{array}{l}\text { in the distal third } \\
\text { of the tail }\end{array}$} & \multicolumn{3}{|c|}{$\begin{array}{l}\text { in the middle } \\
\text { of the tail }\end{array}$} & \multicolumn{3}{|c|}{$\begin{array}{l}\text { in the proximal } \\
\text { third of the tail }\end{array}$} \\
\hline & q & đ & juv. & q & o & juv. & q & $0^{\top}$ & juv. & 운 & $\sigma^{\top}$ & juv. & $q$ & $\sigma^{\star}$ & juv. \\
\hline P. caucasia & $\begin{array}{c}105 \\
(43.3)\end{array}$ & $\begin{array}{c}130 \\
(54.9)\end{array}$ & $\begin{array}{c}2 \\
(0.8)\end{array}$ & $\begin{array}{c}66 \\
(27.8)\end{array}$ & $\begin{array}{c}80 \\
(33.8)\end{array}$ & $\begin{array}{c}2 \\
(0.8)\end{array}$ & $\begin{array}{c}31 \\
(13.1)\end{array}$ & $\begin{array}{c}41 \\
(17.3)\end{array}$ & $\begin{array}{c}0 \\
(0.0)\end{array}$ & $\begin{array}{c}4 \\
(1.7)\end{array}$ & $\begin{array}{c}8 \\
(3.4)\end{array}$ & $\begin{array}{c}0 \\
(0.0)\end{array}$ & $\begin{array}{c}4 \\
(1.7)\end{array}$ & $\begin{array}{c}1 \\
(0.4)\end{array}$ & $\begin{array}{c}0 \\
(0.0)\end{array}$ \\
\hline P. erythrogaster & $\mid \begin{array}{c}9 \\
(32.1)\end{array}$ & $\begin{array}{c}19 \\
(67.9)\end{array}$ & $\begin{array}{c}0 \\
(0.0)\end{array}$ & $\begin{array}{c}5 \\
(17.9)\end{array}$ & $\begin{array}{c}10 \\
(35.7)\end{array}$ & $\begin{array}{c}0 \\
(0.0)\end{array}$ & $\begin{array}{c}3 \\
(10.7)\end{array}$ & $\begin{array}{c}7 \\
(25.0)\end{array}$ & $\begin{array}{c}0 \\
(0.0)\end{array}$ & $\begin{array}{c}0 \\
(0.0)\end{array}$ & $\begin{array}{c}1 \\
(3.6)\end{array}$ & $\begin{array}{c}0 \\
(0.0)\end{array}$ & $\begin{array}{c}1 \\
(3.6)\end{array}$ & $\begin{array}{c}1 \\
(3.6)\end{array}$ & $\begin{array}{c}0 \\
(0.0)\end{array}$ \\
\hline P. himalayana & $\begin{array}{c}15 \\
(33.3)\end{array}$ & $\begin{array}{c}20 \\
(44.4)\end{array}$ & $\begin{array}{c}10 \\
(22.2)\end{array}$ & $\begin{array}{c}6 \\
(13.3)\end{array}$ & $\begin{array}{c}14 \\
(31.1)\end{array}$ & $\begin{array}{c}10 \\
(22.2)\end{array}$ & $\begin{array}{c}6 \\
(13.3)\end{array}$ & $\begin{array}{c}3 \\
(6.7)\end{array}$ & $\begin{array}{c}0 \\
(0.0)\end{array}$ & $\begin{array}{c}3 \\
(6.7)\end{array}$ & $\begin{array}{c}2 \\
(4.4)\end{array}$ & $\begin{array}{c}0 \\
(0.0)\end{array}$ & $\begin{array}{c}0 \\
(0.0)\end{array}$ & $\begin{array}{c}1 \\
(2.2)\end{array}$ & $\begin{array}{c}0 \\
(0.0)\end{array}$ \\
\hline P. lehmanni & $\begin{array}{c}113 \\
(62.1)\end{array}$ & $\begin{array}{c}66 \\
(36.3)\end{array}$ & $\begin{array}{c}3 \\
(1.6)\end{array}$ & $\begin{array}{c}104 \\
(57.1)\end{array}$ & $\begin{array}{c}53 \\
(29.1)\end{array}$ & $\begin{array}{c}2 \\
(1.1)\end{array}$ & $\begin{array}{c}9 \\
(4.9)\end{array}$ & $\begin{array}{c}11 \\
(6.0)\end{array}$ & $\begin{array}{c}0 \\
(0.0)\end{array}$ & $\begin{array}{c}0 \\
(0.0)\end{array}$ & $\begin{array}{c}2 \\
(1.1)\end{array}$ & $\begin{array}{c}1 \\
(0.5)\end{array}$ & $\begin{array}{c}0 \\
(0.0)\end{array}$ & $\begin{array}{c}0 \\
(0.0)\end{array}$ & $\begin{array}{c}0 \\
(0.0)\end{array}$ \\
\hline P. microlepis & $\begin{array}{c}1 \\
(20.0)\end{array}$ & $\mid \begin{array}{c}4 \\
(80.0)\end{array}$ & $\begin{array}{c}0 \\
(0.0)\end{array}$ & $\begin{array}{c}0 \\
(0.0)\end{array}$ & $\begin{array}{c}2 \\
(40.0)\end{array}$ & $\begin{array}{c}0 \\
(0.0)\end{array}$ & $\begin{array}{c}1 \\
(20.0)\end{array}$ & $\begin{array}{c}2 \\
(40.0)\end{array}$ & $\begin{array}{c}0 \\
(0.0)\end{array}$ & $\begin{array}{c}0 \\
(0.0)\end{array}$ & $\begin{array}{c}0 \\
(0.0)\end{array}$ & $\begin{array}{c}0 \\
(0.0)\end{array}$ & $\begin{array}{c}0 \\
(0.0)\end{array}$ & $\begin{array}{c}0 \\
(0.0)\end{array}$ & $\begin{array}{c}0 \\
(0.0)\end{array}$ \\
\hline P. stoliczkana & $\begin{array}{c}51 \\
(43.6)\end{array}$ & $\begin{array}{c}65 \\
(55.6)\end{array}$ & $\begin{array}{c}1 \\
(0.9)\end{array}$ & $\begin{array}{c}40 \\
(34.2)\end{array}$ & $\begin{array}{c}44 \\
(37.6)\end{array}$ & $\begin{array}{c}1 \\
(0.9)\end{array}$ & $\begin{array}{c}11 \\
(9.4)\end{array}$ & $\begin{array}{c}21 \\
(17.9)\end{array}$ & $\begin{array}{c}0 \\
(0.0)\end{array}$ & $\begin{array}{c}0 \\
(0.0)\end{array}$ & $\begin{array}{c}0 \\
(0.0)\end{array}$ & $\begin{array}{c}0 \\
(0.0)\end{array}$ & $\begin{array}{c}0 \\
(0.0)\end{array}$ & $\begin{array}{c}0 \\
(0.0)\end{array}$ & $\begin{array}{c}0 \\
(0.0)\end{array}$ \\
\hline
\end{tabular}

Percentages are shown in parentheses. When calculating the percentage of cases of detection of lizards with normal tails and autotomy, the number of specimens of each sex was taken as $100 \%$.

However, the compliance of sexes by this trait is broken by the predominance of males over females in the series (67.9 and $32.1 \%$, respectively) and cannot be considered significant. As in the previous case, autotomy most often occurs in the distal third of the tail; cases with autotomy in the middle and in the proximal third of the tail are few.

Out of the 45 specimens of P. himalayana, 30 (66.7\%) had intact tails and $15(33.3 \%)$ had autotomy in the distal third $(13.3 \%$ of females and $6.7 \%$ of males), proximal third (2.2\% of males), and in the middle ( $6.7 \%$ of females and $4.4 \%$ of males) of the tail.

The smallest number of specimens with autotomy in the series presented was found for P. lehmanni (12.6\%). Since the number of females in this sample was significantly larger than the number of males (for all nonparametric criteria, $P<0.05$ ), an analysis of sexual dimorphism would not give a correct result and, for this reason, was not performed. Nevertheless, the majority of specimens $(10.9 \%)$ were autotomized in the distal third of the tail, and $1.6 \%$ (two specimens, one of which was juvenile) were autotomized in the middle of the tail. Since the sample of $P$. microlepis is unrepresentative (five specimens), a detailed analysis of the frequencies of occurrence of autotomy would be unjustified. Nevertheless, three specimens with autotomy in the distal third of the tail were recorded.

In P. stoliczkana, the proportion of specimens with autotomy was $27.4 \%$, the proportions of females and males were 9.4 and $17.9 \%$, respectively. All specimens shed tails in the distal third of the tail. Out of the 614 specimens analyzed, 16 were juvenile, of which only one (P. lehmanni, no. ZISP 13462) was autotomized in the distal third of the tail.

Despite the differences in the frequencies of occurrence of autotomized and nonautotomized specimens of males and females, the probability of finding a female or a male with a shed or regenerated tail is the same for all species considered, which is typical for the majority of lizard species (Bateman and Fleming, 2009; Arribas, 2014; Pafilis et al., 2017). The studies of the frequency of occurrence of autotomy (Bowen, 2004) using Nerodia sipedon (Linnaeus, 1758) as an example showed that the sample size may be a critical factor. Significant differences in the frequencies of occurrence of different categories of the state of the tail between males and females were not revealed either; however, it is most likely that the tail is discarded in the distal part.

The location of the region in which the tail will be discarded depends on a number of circumstances. Firstly, this is determined by the possibility of autotomy in a particular region: nonautotomic (pygal) vertebrae, located at the base of the tail, and autotomic (postpygal) vertebrae, located after them, are distinguished. Their number varies in different genera and species as well as within the limits of variability in the same species (Bellairs and Bryant, 1985). This is true for the species with the IntraVB autotomy mechanism. A characteristic feature of a number of species (e.g., Iguana iguana (Linnaeus, 1758), Cyclura spp., Ctenosaura acanthura (Shaw, 1802), as well as the species of the genera Sauromalus Duméril, 1856, Basiliscus Laurenti, 1768, Enyalioides Boulenger, 1885, etc.) is the age-related changes in the anatomy of the caudal vertebrae: fusion of both fragments of the IntraVB-verte- 
brae in the distal part or throughout the tail, resulting in partial or complete loss of the capability of autotomy (Arnold, 1988). Secondly, the break site location depends on the tail part that is grasped by the predator (Borkin et al., 2007) or another individual of the same species of lizards. It should be noted that the autotomic tissue rupture always occurs only slightly (no more than three segments) above the grasp site. This is explained by the significant energy expenditures for subsequent regeneration and a decrease in the locomotor activity of such individuals (Lin et al., 2006). The dependence on the lifestyle of a particular species is also likely.

It is known that, in most lizards, autotomy is followed by tail regeneration (true autotomy, as opposed to pseudo-autotomy, which ends with wound healing without the formation of a regenerate). The regenerate is usually shorter than the original tail and differs significantly from it in the pholidosis structure. The rate of regeneration depends on environmental conditions, age, nutritional intensity, individual characteristics, and the biology of the species (Bellairs and Bryant, 1985; Arnold, 1988). The final size of the regenerate may also show interspecific differences (Bellairs and Bryant, 1985).

As noted above, some agamid lizards are capable of InterVB autotomy and regeneration, which distinguishes them from all other lepidosaurs. Regenerated regions have a specific shape, which may vary slightly within the species. For Agama agama and A. stellio (=Stellagama stellio (Linnaeus 1758)), three types of regenerates are known (Schall et al., 1989): narrowed, club-shaped, and conically regenerated tails, which usually form much shorter regenerated structures. In the museum material analyzed, in six species of agamas of the genus Paralaudakia, we identified six types of regenerates (Fig. 1):

- knob-shaped jagged (the width of the regenerate along its entire length is approximately equal to the width of the last ring of the tail above the autotomy site); its covering scales have a jagged shape, and one edge of them is somewhat bent outwards;

-knob-shaped smooth (similar to the previous type, but the covering scales are tightly attached to the regenerate and do not form thornlike structures);

- conical jagged (gradually tapering regenerate from the base to the end of the tail, the scales covering it have a jagged shape, one edge of them is slightly bent outwards;

- conical smooth (similar to the conical jagged one, but the covering scales tightly adjoin the regenerate and do not form thornlike structure);

-club-shaped ("teeth" are present, the width of the regenerate is approximately equal to or slightly larger, and its base is substantially narrower than the width of the last ring of the tail above the site of autotomy);

-narrowed ("teeth" are absent, the regenerate has the same width over the entire length and is substan- tially narrower than the last tail ring above the site of autotomy).

The ratio of the described types of regenerates in different types of agamas is not the same. Since most of the specimens examined had either damaged tails (the significance of autotomy is in doubt) or regenerates at an early stage, the type of regenerate was reliably identified only for a small part of the specimens (Table 2). Of the five specimens of $P$. microlepis, three (one female and two males) were autotomized; however, the size of the regenerates did not allow reliable identification of their types. The pineal jagged regenerate, the most common and found in all species considered, dominated in $P$. caucasia, $P$. himalayana, and $P$. lehmanni and, depending on the species, accounted for 42.9 to $100.0 \%$ of the reliably determined regenerates. The rare forms of regenerates-conical jagged and conical smooth-are characteristic only of P. stoliczkana. The greatest diversity of the types of regenerates (five out of six) was found in P. stoliczkana, whereas in P. lehmanni the only form was the knobshaped jagged type. The narrowed regenerate predominated in the samples of $P$. erythrogaster and P. stoliczkana (50.0 and $30.8 \%$, respectively).

Some species close to the genus Paralaudakia (e.g., Laudakia nupta (De Filippi, 1843)) had regenerates of similar types: knob-shaped jagged, knob-shaped smooth, and conical smooth (Gordeev and Anan'eva, 2019). The volume of our data does not allow us to make conclusions about the sex-related differences in the types of regenerates; however, the knob-shaped jagged (club-shaped) type dominates in most species (Schall et al., 1989) in both males and females.

On the basis of the results of a field experiment (Schall et al., 1989), in which the majority of males ( $78.6 \%$ versus $19.3 \%$ of females) had club-shaped regenerates, whereas females had regenerates of the narrowed type, it was assumed that the club shape of the regenerate has a certain adaptive advantage in social behavior (in competitions between males, because massive tails can strike stronger blows).

After the tail is shed, the remaining part of the tail has a markedly protruding vertebra and, partially, muscles. Later, the vertebra that became distal undergoes partial ablation, which is clearly seen on the X-ray micro-CT sections (Fig. 2).

The micro-CT image analysis and visual inspection of the shed tail indicates that the autotomy region does not pass clearly between the vertebrae but is repeatedly bent. Superficially (dorsally) the autotomy region is located between the scales of the tail opposite the junction of two vertebrae. Then, it deviates slightly towards the head region and, after reaching the vertebra, goes to its distal part, then passes between the adjacent vertebrae, and again goes to the head section. Thereafter, the caudal artery and vein are broken, the plane of the fracture is directed to the lower spinous process of the adjacent vertebra and again turns for- 
(a)

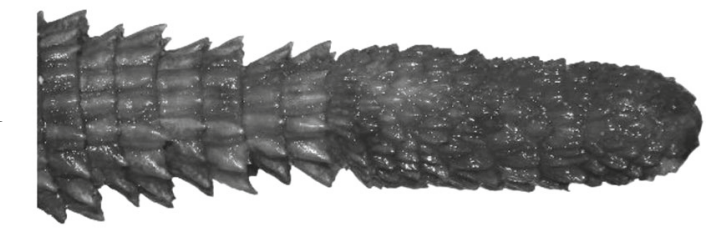

2

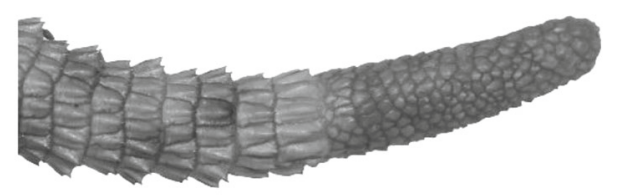

3

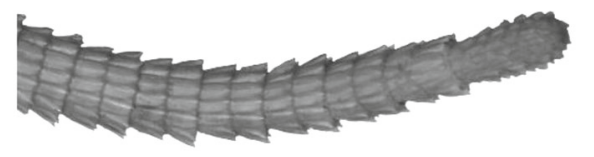

4

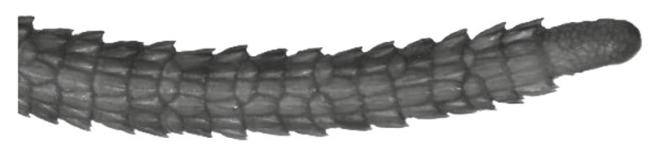

(b)

5

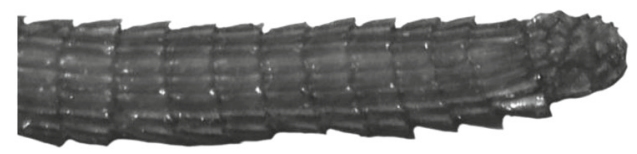

6
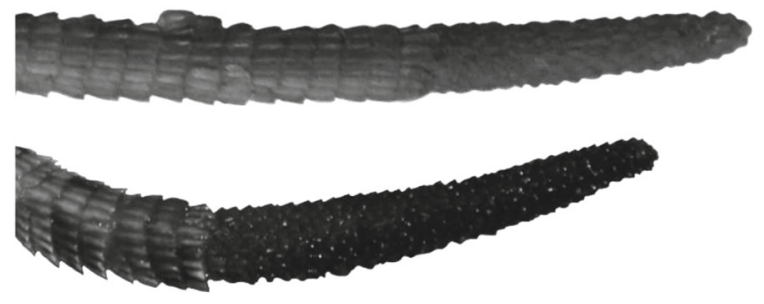

8

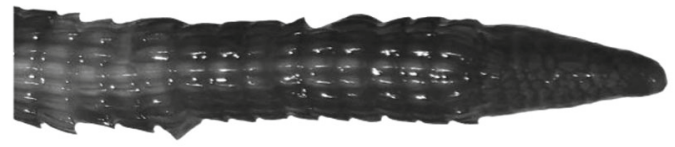

(c)

10

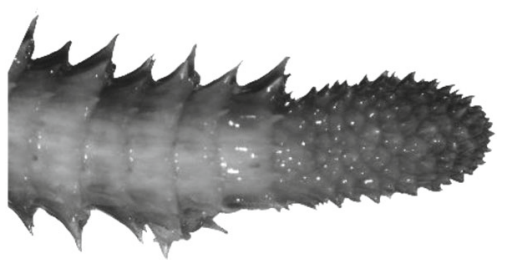

11

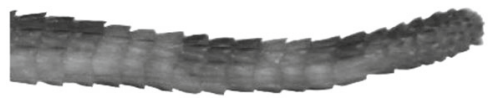

12

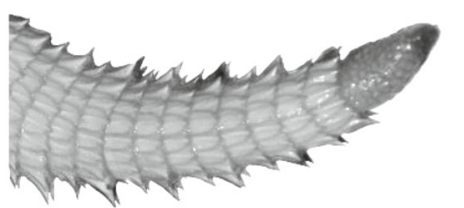

(d)

13

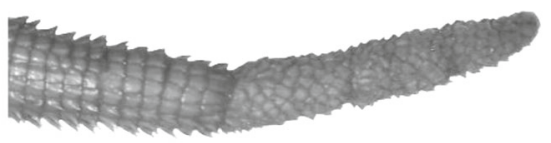

14

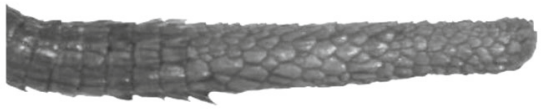

15

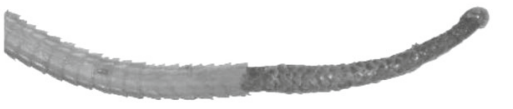

(e)

16

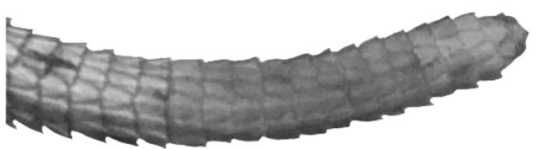

9

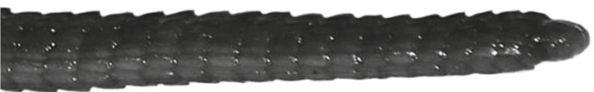

Fig. 1. Tails of agamas of the genus Paralaudakia. (a) P. caucasia: 1, knob-shaped jagged (village of Khodzhib, May 5, 1904; N.A. Zarudnyi, ZISP 10426); 2, knob-shaped smooth (Iran, May 31, 1942; E.N. Pavlovskii, ZISP 18245.1); 3, club-shaped (Turkmenistan, Atrek Valley, September 29, 1972; Eremin, ZISP 19116.4); 4, narrowed (Turkmenistan, vicinities of Ashgabat, July 1972; R.I. Zubarev, ZISP 19117.8). (b) P. stoliczkana: 5, knob-shaped jagged (Mongolia, Hatan-Khayrhan-Ula Mountains, July 17, 1986; V.F. Orlova, ZMMSU R-5740); 6, knob-shaped smooth (Mongolia, Gobi-Altai Aimak, August 21, 2005; A.V. Surov, ZMMSU R-12041); 7, conical jagged (Mongolia, Gobi-Altai Aimak, Elgen, July 13, 1983; L.Ya. Borkin, N.L. Orlov, D.V. Semenov, ZISP 19839); 8, conical smooth (Mongolia, Gobi-Altai Aimak, Elgen, July 13, 1983; L.Ya. Borkin, N.L. Orlov, D.V. Semenov, ZISP 19839); 9, narrowed (Mongolia, Gobi-Altai Aimak, Elgen, July 13, 1983; L.Ya. Borkin, N.L. Orlov, D.V. Semenov, ZISP 19839). (c) P. erythrogaster: 10, knob-shaped jagged (Turkmenistan, Badkhyz Reserve, June 1, 1970; Z.Ya. Kamalova, ZISP 18844); 11, club-shaped (Iran, vicinities of Mazduran, Khorasan province, 2010; R.A. Nazarov, ZMMSU R-13517); 12, narrowed (Turkmenistan, Badkhyz, June 22, 1948; V.G. Geptner, ZMMSU R-9562). (d) P. himalayana: 13, knobshapedjagged (Darvaz, 1987; A.N. Kaznakov, ZMMSU 251); 14, knob-shaped smooth (Noman-Gut, Tien Shan spurs, Bukhara estates, N.V. Bogoyavlenskii, ZMMSU 256); 15, narrowed (Tajikistan, Panj Coast, Western Pamir, July 1966; A.G. Bannikov, ZMMSU 3324). (d) P. lehmanni: 16, knob-shaped jagged (Uzbekistan, Samarkand oblast, northern slopes of Ak-Tau, environs of the village of Sarai-Bulak, August 1972, I. Dolzhanskii, ZISP 20117). 
Table 2. Frequencies of occurrence of regenerate types in some agamas of the genus Paralaudakia

\begin{tabular}{|c|c|c|c|c|c|c|c|}
\hline \multirow[b]{2}{*}{ Sex } & \multirow[b]{2}{*}{$\begin{array}{l}\text { Number } \\
\text { of specimens } \\
\text { with reliably } \\
\text { identified } \\
\text { regenerate }\end{array}$} & \multicolumn{6}{|c|}{ Types of regenerates } \\
\hline & & 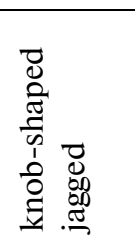 & 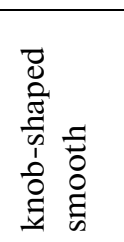 & 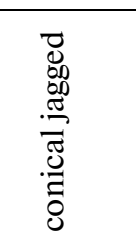 & 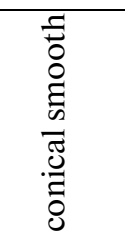 & 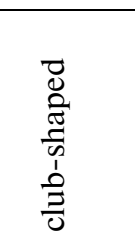 & 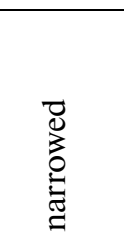 \\
\hline \multicolumn{8}{|c|}{ P. caucasia } \\
\hline 우 & 16 & $8(22.9)$ & $1(2.9)$ & $0(0.0)$ & $0(0.0)$ & $2(5.7)$ & $0(0.0)$ \\
\hline 0 & 19 & $7(20.0)$ & $3(8.6)$ & $0(0.0)$ & $0(0.0)$ & $7(20.0)$ & $0(0.0)$ \\
\hline \multicolumn{8}{|c|}{ P. erythrogaster } \\
\hline ㅇ & 3 & $1(16.7)$ & $0(0.0)$ & $0(0.0)$ & $0(0.0)$ & $1(16.7)$ & $1(16.7)$ \\
\hline 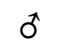 & 3 & $1(16.7)$ & $0(0.0)$ & $0(0.0)$ & $0(0.0)$ & $0(0.0)$ & $2(33.3)$ \\
\hline \multicolumn{8}{|c|}{ P. himalayana } \\
\hline 우 & 5 & $2(22.2)$ & $1(11.1)$ & $0(0.0)$ & $0(0.0)$ & $0(0.0)$ & $2(22.2)$ \\
\hline 0 & 4 & $3(33.3)$ & $0(0.0)$ & $0(0.0)$ & $0(0.0)$ & $0(0.0)$ & $1(11.1)$ \\
\hline \multicolumn{8}{|c|}{ P. lehmanni } \\
\hline o & 3 & $3(75.0)$ & $0(0.0)$ & $0(0.0)$ & $0(0.0)$ & $0(0.0)$ & $0(0.0)$ \\
\hline 0 & 1 & $1(25.0)$ & $0(0.0)$ & $0(0.0)$ & $0(0.0)$ & $0(0.0)$ & $0(0.0)$ \\
\hline \multicolumn{8}{|c|}{ P. stoliczkana } \\
\hline 우 & 9 & $1(7.7)$ & $1(7.7)$ & $3(23.1)$ & $1(7.7)$ & $0(0.0)$ & $3(23.1)$ \\
\hline 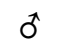 & 4 & $1(7.7)$ & $0(0.0)$ & $0(0.0)$ & $2(15.4)$ & $0(0.0)$ & $1(7.7)$ \\
\hline
\end{tabular}

Percentages are shown in parentheses.

ward, going between the adjacent tail scales. In the Paralaurakia species considered here, among the structures associated with the autotomy region, there is no adipose tissue, unlike that in the tails of the lizards with the IntraVB autotomy (Bellairs and Bryant, 1985). The absence of adipose tissue is probably characteristic of the majority of Agamidae (Bellairs and Bryant, 1985). Later, the major part of the vertebra that became distal and the soft tissues surrounding it undergo obliteration.

The resulting regenerate (Fig. 2) includes the regenerated skin, muscles, and cartilaginous tube, which serves as the spine (with the spinal cord passing through it). Longitudinal septa formed by connective tissue, which separates muscle bundles, protrude radially from the cartilaginous tube. An analysis of the anatomical structure of the two types of regenerates (narrowed and pineal jagged) did not reveal significant differences in the elements and the structures composing them. However, additional studies of the anatomy, histology, and biochemistry of the types of regenerates are necessary, because they will help to explain the mechanism of their formation.

Nevertheless, there are significant anatomical and morphological differences in the structure of the regenerate and the original tail, which is characteristic of the majority of lizards: the scales covering the regenerate are smaller and have no strict shape, which can be influenced (at least in geckos) by temperature fluctuations (Bellairs and Bryant, 1985); muscle fibers are less structured, the number of radial connectivetissue septa is much larger; the cartilaginous tube of the regenerated area replacing the vertebrae remains for life.

Another important aspect in the studies of caudal autotomy is the phylogenetic transformations of the ways of tail shedding and the possibility of their realization in different evolutionary lines of reptiles. According to the modern concepts, the monophyly of the clade Acrodonta (Chamaeleonidae + Agamidae) is reliably confirmed (Ananjeva, 2004; Pyron et al., 2013). It includes both species that are incapable of autotomy and species with the InterVB autotomy, also discarding the tail either without forming a regenerate or showing a pronounced ability to regenerate. Chamaeleonidae as a sister group for Agamidae combines only the nonautotomic species. The family Agamidae is more interesting in this regard, because it includes species with the InterVB mechanism of autotomy that have lost it, as well as species capable of shedding the tail without subsequent regeneration or with the formation of regenerates. The subfamily Uromastycinae includes only nonautotomic species. Among the agamas of the subfamily Amphibolurinae, lizards of the terminal taxa Diporiphora Gray, 1842 can shed the tail but do not regenerate it, whereas lizards of the taxa 


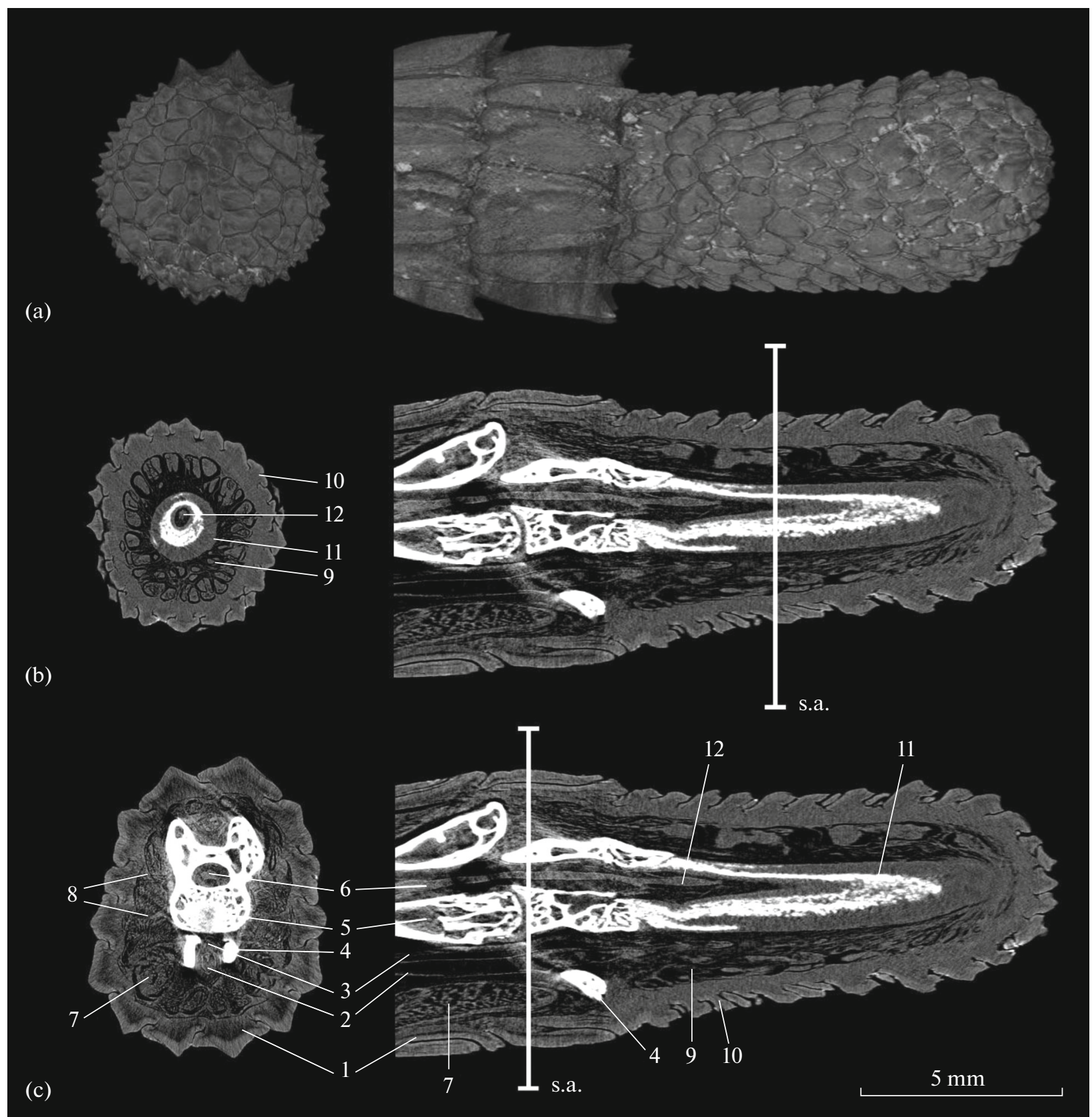

Fig. 2. Result of computer microtomography of a Paralaudakia caucasia tail (Turkmenistan, Balkhan Province, Chandyr Valley, lower reaches of the Sumbar River, March 4, 1968, ZMMSU no. 15396) with a narrowed regenerate. (a) 3D model of the distal part of the tail with the regenerate: the frontal and sagittal planes are shown on the left and right, respectively. (b) X-ray density sections through the frontal plane in the middle of the regenerate (on the left) and the sagittal plane through the middle of the tail. (c) X-ray density sections through the frontal plane at the beginning of the last vertebra preceding the autotomy region (on the left) and the sagittal plane through the middle of the tail (on the right). Designations: 1, scales; 2, tail vein; 3, caudal artery; 4 , lower spinous process of the vertebra; 5 , the body of the caudal vertebra; 6 , spinal cord; 7 , muscles; 8 , radial longitudinal septae; 9, regenerated muscles; 10 , regenerated scales; 11 , cartilaginous tube; 12 , spinal cord in the regenerated part of the tail; s.a., section areas in the frontal plane shown on the left side of the figure. To avoid cluttering the picture, some elements are not marked repeatedly.

(genera) close to the basal ones (Intellagama Wells and Wellington, 1985 and Ctenophorus Fitzinger, 1843) are able to shed and regenerate the tail. The genera Laudakia Gray, 1845 and Paralaudakia Baig, Wagner, Ananjeva and Böhme, 2012, which are basal for the rest of Agaminae and Agama Daudin, 1802 (terminal group), undergo autotomy fairly easily, whereas many other representatives of this subfamily (e.g., Phrynocephalus Kaup, 1825 and Trapelus Cuvier, 1817) have completely lost this defensive mechanism. Some rep- 
resentatives of the subfamily Draconinae (e.g., Sitana Cuvier, 1829 and Otocryptis Wagler, 1830) do not regenerate shed tails. Thus, in many phylogenetic lines of Agamidae, the ability of autotomy was lost for a second time, and in those species that retained (or restored) it, it never proceeds through the IntraVB pathway. Apparently, this pathway of autotomy was lost by the ancestral forms of Acrodonta, and its restoration requires significant rearrangement of the tail anatomy and, hence, is hampered. The presence of fracture planes and the IntraVB way of autotomy in representatives of the infraorder Iguania (e.g., in Dipsosaurus dorsalis (Baird and Girard, 1852), sister for Chamelionidae + Agamidae), probably indicates that the latter separated from the common trunk Iguania, having lost the plane of the fracture in the vertebral body.

\section{CONCLUSIONS}

Thus, for the six species of agamas of the genus Paralaudakia considered in this study, autotomy with subsequent regeneration can be considered a common phenomenon. However, the number of such specimens is less than the number of specimens with intact tails. The tail is usually shed in the distal third, which compensates for the costs of subsequent regeneration and also allows avoiding an undesirable decrease in locomotor activity and reproductive ability. The number of specimens with autotomy in the middle and proximal third of the tail is minimal for all species. Since the regenerate significantly differs externally from the original tail, at least six variations can be distinguished: knob-shaped jagged, knob-shaped smooth, narrowed, club-shaped, conical jagged, and conical smooth. Among these types, the knob-shaped jagged regenerate is most common. Four types of regenerates are characteristic of $P$. caucasia; three types, of $P$. erythrogaster and $P$. himalayana; five types, of $P$. stoliczkana; and one type, of P. lehmanni. The analysis of the anatomical structure of the narrowed and knob-shaped jagged regenerates did not reveal significant differences in their constituent elements and structures. Nevertheless, additional studies of the anatomy, histology, and biochemistry of the types of regenerates are desirable because they will help explain the mechanism of their formation.

\section{ACKNOWLEDGMENTS}

We are grateful to V.F. Orlova, head of the herpetology sector of the Zoological Museum of Moscow State University, for providing the opportunity to work with the herpetological collection of the Zoological Museum, Moscow State University; R.A. Nazarov (Zoological Museum, Moscow State University) for help in the organization of work with microcomputed tomography; and I.V. Doronin (Zoological Institute, Russian Academy of Sciences) for help in selecting the literature.

\section{FUNDING}

This work was supported by the Russian Foundation for Basic Research (project nos. 19-14-50038 "Expansion" and 18-04-00040).

\section{COMPLIANCE WITH ETHICAL STANDARDS}

The authors declare that they have no conflict of interest. This article does not contain any studies involving animals or human participants performed by any of the authors.

\section{OPEN ACCESS}

This article is distributed under the terms of the Creative Commons Attribution 4.0 International License (http://cre-ativecommons.org/licenses/by/4.0/), which permits unrestricted use, distribution, and reproduction in any medium, provided you give appropriate credit to the original author(s) and the source, provide a link to the Creative Commons license, and indicate if changes were made.

\section{REFERENCES}

Alibardi, L., Localization of proliferating cells in the intervertebral region of the developing and adult vertebrae of lizards in relation to growth and regeneration, Anat. Rec., 2016, vol. 299, pp. 461-473.

Alibardi, L., Review: biological and molecular differences between tail regeneration and limb scarring in lizard: an inspiring model addressing limb regeneration in amniotes, $J$. Exp. Zool. (Mol. Dev. Evol.), 2017, vol. 328, no. 6, pp. 493514.

Alibardi, L. and Maderson, P.F.A., Observations on the histochemistry and ultrastructure of regenerating caudal epidermis of the tuatara Sphenodon punctatus (Sphenodontida, Lepidosauria, Reptilia), J. Morphol., 2003, vol. 256, pp. 134-145.

Ananjeva, N.B., Phylogeny and biogeography of agamid lizards (Agamidae, Lacertilia, Reptilia): a review of the concepts and results of molecular and morphological studies, Usp. Sovrem. Biol., 2004, vol. 124, no. 1, pp. 44-46.

Ananjeva, N.B. and Danov, RA., A rare case of bifurcated caudal regeneration in the Caucasian agama, Stellio caucasius, Amphibia-Reptilia, 1991, vol. 12, pp. 343-356.

Ananjeva, N.B. and Orlov, N.L., Caudal autotomy in colubrid snake Xenochrophis piscator from Vietnam, Russ. J. Herpetol., 1994, vol. 1, no. 2, pp. 169-171.

Arnold, E.N., Evolutionary aspects of tail autotomy in lizards and their relatives, Nat. Hist., 1984, vol. 18, pp. 127169.

Arnold, E.N., Caudal autotomy as a defense, in Biology of the Reptilia, vol. 16: Ecology B, Gans, C. and Huey, R., Eds., New York: Alan R. Liss, Inc., 1988, pp. 235-273.

Arribas, O.J., Autotomía caudal en las lagartijas de alta montaña de los Pirineos (Iberolacerta Arribas, 1997), Butll. Soc. Catalana d'Herpetologia, 2014, vol. 21, pp. 115-126.

Bateman, P.W. and Fleming, P.A., To cut a long tail short: a review of lizard caudal autotomy studies carried out over the last 20 years, J. Zool., 2009, vol. 277, no. 1, pp. 1-14. 
Bellairs, A.d'A. and Bryant, S.V., Autotomy and regeneration in reptiles, in Biology of the Reptilia, vol. 15: Development B, Gans, C. and Billett, F., Eds., New York: Wiley, 1985, pp. 303-410.

Borkin, L.Ya., Eremchenko, V.K., and Panfilov, A.M., On the ecology of the skink gecko (Teratoscincus scincus), Sovrem. Gerpetol., 2007, vol. 7, no. 1/2, pp. 16-56.

Bowen, K.D., Frequency of tail breakage of the northern watersnake, Nerodia sipedon sipedon, Can. Field Natur., 2004, vol. 118, no. 3, pp. 435-437.

Chapple, D.G. and Swain, R., Effect of caudal autotomy on locomotor performance in a viviparous skink, Niveoscincus metallicus, Funct. Ecol., 2002, vol. 16, pp. 817-825.

Costa, H.C., Moura, M.R., and Feio, R.N., A tale of lost tails: pseudoautotomy in the neotropical snake genus Drymoluber (Serpentes: Colubridae), Can. J. Zool., 2014, vol. 92, pp. 811-816.

Crnobrnja-Isalović, J., Corović, J., and Halpern, B., Deliberate tail loss in Dolichophis caspius and Natrix tessellate (Serpentes: Colubridae) with a brief review of pseudoautotomy in contemporary snake families, North-Western J. Zool., 2016, vol. 12, no. 2, pp. 367-372.

Dudek, K. and Ekner-Grzyb, A., Field observation of twotailed sand lizard Lacerta agilis Linnaeus, 1758 and a common lizard Zootoca vivipara (Jacquin, 1787) in Poland, Nat. Sloveniae, 2014, vol. 16, no. 1, pp. 65-66.

Fleming, P.A., Valentine, L.E., and Bateman, P.W., Telling tails: selective pressures acting on investment in lizard tails, Physiol. Biochem. Zool., 2013, vol. 86, no. 6, pp. 645-658.

Gordeev, D.A., Cases of incomplete autotomy and disturbance in the tail regeneration in the multicolored lizard ( $E r$ emias arguta (Pallas, 1773)) and sand lizard (Lacerta agilis Linnaeus, 1758) in the Volgograd oblast, Sovrem. Gerpetol., 2017, vol. 17, no. 1/2, pp. 3-9.

Gordeev, D.A. and Anan'eva, N.B., On the strategy of defensive behavior of some representatives of agamas of the genus Paralaudakia Baig, Wagner, Ananjeva and Böhme, Izv. Vuzov. Povolzhsk. Region., Estestv. Nauki, 2019, no. 1 (25), pp. 20-27.

Higham, T.E., Anthony, P., Russell, A.P., Peter, A., and Zani, P.A., Integrative biology of tail autotomy in lizards, Physiol. Biochem. Zool., 2013, vol. 86, no. 6, pp. 603-610.

Hutchins, E.D., Eckalbar, W.L., Wolter, J.M., Mangone, M., and Kusumi, K., Differential expression of conserved and novel microRNAs during tail regeneration in the lizard Anolis carolinensis, BMC Genom., 2016.

https://doi.org/10.1186/s12864-016-2640-3

Jagnandan, K., Russell, A.P., and Higham, T.E., Tail autotomy and subsequent regeneration alter the mechanics of locomotion in lizards, J. Exp. Biol., 2014, vol. 217, pp. 3891-3897.

Kolenda, K., Wieczorek, M., Najbar, A., Najbar, B., and Skawinski, T., Limb malformation and tail bifurcation in sand lizards (Lacerta agilis) and common lizards (Zootoca vivipara) from Poland, Herpetol. Not., 2017, vol. 10, pp. 713-716.

Koleska, D., First record of tail bifurcation in Asaccus gallagheri from the United Arabian Emirates, Herpetol. Not., 2018, vol. 11, pp. 115-116.
Koleska, D. and Jablonski, D., Tail trifurcation recorded in Algyroides nigropunctatus (Duméril \& Bibron, 1839), Ecol. Montenegr., 2015, vol. 3, pp. 26-28.

Kukushkin, O.V., On the abnormalities of regeneration and autotomy of the tail in the Crimean gecko, Mediodactylus danilewskii (Reptilia, Sauria, Gekkonidae), Sovrem. Gerpetologiya, 2018, vol. 18, no. 3/4, pp. 180-187.

Lin, Z.-H., Qu, Y.-F., and Ji, X., Energetic and locomotor costs of tail loss in the Chinese skink, Eumeces chinensis, Comp. Biochem. Physiol. A, 2006, vol. 143, pp. 508-513.

Lozito, T.P. and Tuan, R.S., Lizard tail regeneration: regulation of two distinct cartilage regions by Indian hedgehog, Dev. Biol., 2015, vol. 399, pp. 249-262.

Lozito, T.P. and Tuan, R.S., Lizard tail skeletal regeneration combines aspects of fracture healing and blastemabased regeneration, Development, 2016, vol. 143, pp. 29462957.

Maria, M. and Al-Razi, H., Observation of tail bifurcation in Hemidactylus frenatus (Schlegel, 1836), Herpetol. Not., 2018, vol. 11, pp. 953-954.

Meyer, V., Preest, M.R., and Lochetto, S.M., Physiology of original and regenerated lizard tails, Herpetologica, 2002, vol. 58, no. 1, pp. 75-86.

Pafilis, P., Valakos, E.D., and Foufopoulos, J., Comparative postautotomy tail activity in six Mediterranean lacertid lizard species, Physiol. Biochem. Zool., 2005, vol. 78, no. 5, pp. 828-838.

Pafilis, P., Sagonas, K., Kapsalas, G., Foufopoulos, J., and Valakos, E., Sex does not affect tail autotomy in lacertid lizards, Acta Herpetol., 2017, vol. 12, no. 1, pp. 19-27.

Passos, D.C., Pedro Fonseca, H.M., Romo de Vivar, P.R., Kanayama, C.Y., Teixeira, V.P.A., and Martinelli, A.G., Tail trifurcation in the lizard Salvator merianae (Squamata: Teiidae) investigated by computer tomography, Phyllomedusa, 2016, vol. 15, no. 1, pp. 79-83.

Pelegrin, N. and Leão, S.M., Injured Salvator merianae (Teiidae) regenerates six tails in central Argentina, Cuad. Herpetol., 2016, vol. 30, no. 1, pp. 21-23.

Pheasey, H., Smith, P., Brouard, J.P., and Atkinson, K., Vanzosaura rubricauda (red-tailed vanzosaur) bifurcation and trifurcation, Herpetol. Rev., 2014, vol. 45, pp. 138-139.

Pillai, A., Desai, I., and Balakrishnan, S., Pharmacological inhibition of fgfr1 signaling attenuates the progression of tail regeneration in the northern house gecko Hemidactylus flaviviridis, Int. J. Life Sci. Biotechn. Pharm. Res., 2013, vol. 2, no. 4, pp. 263-278.

Pyron, R.A., Burbrink, F.T., and Wiens, J.J., A phylogeny and revised classification of Squamata, including 4161 species of lizards and snakes, BMC Evol. Biol., 2013, vol. 13, no. 93, pp. 1-53.

Ramadanović, D. and Zimić, A., Record of a Lacerta agilis Linnaeus, 1758 with erythronotus colour morph and tail bifurcation, Herpetol. Not., 2019, vol. 12, pp. 779-781.

Savage, J.M. and Slowinski, J.B., Evolution of coloration, urotomy and coral snake mimicry in the snake genus Scaphiodontophis (Serpentes: Colubridae), Biol. J. Linn. Soc., 1996, vol. 57, pp. 129-194. 
Schall, J.J., Bromwich, C.R., Werner, Y.L., and Midlege, J., Clubbed regenerated tails in Agama agama and their possible use in social interactions, J. Herpetol., 1989, vol. 23, pp. 303-305.

Seligmann, H., Moravec, J., and Werner, Y.L., Morphological, functional and evolutionary aspects of tail autotomy and regeneration in the 'living fossil' Sphenodon (Reptilia: Rhynchocephalia), Biol. J. Linn. Soc., 2008, vol. 93, pp. 721-743.

Sun, Y.-Y., Yang, J., and Ji, X., Many-lined sun skinks (Mabuya multifasciata) do not compensate for the costs of tail loss by increasing feeding rate or digestive efficiency, $J$. Exp. Zool., 2009, vol. 311 A, pp. 125-133.

Vergilov, V. and Natchev, N., First record of tail bifurcations in the snake-eyed skink Ablepharus kitaibelii Bibron \& Bory de Saint-Vincent, 1833 from Pastrina hill (northwest- ern Bulgaria), Arxius de Miscel. Zool., 2017, vol. 15, pp. 224-228.

Yadav, M., Buch, P., Desai, I., and Balakrishnan, S., Exogenous administration of EGF augments nucleic acid biosynthesis and cell proliferation in the regenerating tail of wall lizard, Eur. J. Exp. Biol., 2014, vol. 4, no. 2, pp. 113123.

Zamora-Camacho, F.J., Rubiño-Hispán, M.V., Reguera, S., and Moreno-Rueda, G., Does tail regeneration following autotomy restore lizard sprint speed? Evidence from the lacertid Psammodromus algirus, Herpetol. J., 2016, vol. 26, pp. 213-218.

Translated by M. Batrukova 